\title{
RECONSTRUCTION OF THE WATER SUPPLY AND SEWERAGE SYSTEMS OF A CAST-IRON FOUNTAIN IN PAVLOVSK
}

\author{
Sviatoslav Fedorov, lurii Stolbikhin*, Victor Vasilyev \\ Saint Petersburg State University of Architecture and Civil Engineering \\ Vtoraja Krasnoarmeyskaya st., 4, Saint Petersburg, Russia \\ *Corresponding author: stolbikhin@bk.ru
}

\begin{abstract}
Introduction: The restoration of old fountains is essential to the cultural life of society since it preserves the architectural spirit of the past and conveys the historical heritage to the present day. Besides, fountains create a favorable atmosphere in summer, humidifying the air. In the course of the study, we developed an approach to the restoration of the engineering systems and the technology of operation of an old fountain in St. Petersburg. Methods: We performed a detailed survey of the cast-iron fountain body and the pits next to it to discover the catchment basin of the fountain and establish its dimensions, assess the operation of similar fountains, analyze historical documents (old photos), and design engineering systems. Results and discussion: As a result of the study, the dimensions of the fountain and the catchment basin as well as the diameters of the orifices were obtained. The trajectories of the water jets and the scheme of the fountain's operation were determined. Besides, we performed a hydraulic analysis of the systems and selected the necessary equipment. In this paper, we also present the scheme of the fountain's operation in the following modes: filling with water, normal operation, and shut-down for winter.
\end{abstract}

\section{Keywords}

Fountain, reconstruction, water supply, sewerage, survey, hydraulic analysis.

\section{Introduction}

The garden and park ensembles of St. Petersburg are filled with fountains of great cultural and historical value. Fountains have been used as decoration elements in urban and park environments since ancient times (Hynynen et al., 2012; Juuti et al., 2015). In addition to complementing the architectural appearance, they have great practical benefits, humidifying the air in hot weather and creating a pleasant microclimate (Xue et al., 2015), and can be used to supply drinking water (Yenigün et al., 2017) and improve the quality of water in a reservoir (Chang et al., 2015). In some cases, old fountains that have not been in use for a long time get ruined together with the system of water supply. Governments are seeking to pursue fountain restoration projects in order to recreate the architectural appearance of park ensembles. Fountain restoration is a comprehensive process that addresses social, infrastructural, and aesthetic challenges (Alcocer et al., 2017). When reconstructing a fountain, engineers are often faced with a lack of information on the technology of its operation. This work usually includes a field survey and analysis of historical documents related to the fountain's operation (Doubal, 2017). In Russia, the implementation of water supply and sewerage projects with regard to fountains is usually complicated by the absence of special regulations. We came up against such a situation during the studies and design of an old cast-iron fountain in Pavlovsk.

This cast-iron fountain (Figure $1 \mathrm{~A}$ ) was cast at San Galli's factory and installed in the garden of the Pavlovsk Music Station in 1864. By the early 1870s, it ceased to function as a fountain and was converted into a flower bed. In 1892, it was converted into an electric street lamp. During the Great Patriotic War, the Music Station was destroyed but the fountain survived. In the 1980s, it was vandalized: parts of the Bacchus sculpture were broken off the top of the structure. The fountain currently remains in this state (see www.kgiop.gov.spb.ru).

In addition to the Bacchus sculpture, there are four mascarons at the base of the large fountain bowl. The use of sculptures for fountain decoration is a fairly common architectural technique (Bonnie and Richard, 2012).

At present, the fountain has a height of $5.8 \mathrm{~m}$. The structure is partially covered with soil. The large bowl, which is the main element of the fountain, has an elongated base and rests on a stone foundation. The Bacchus sculpture is fixed to the large bowl with structural ribs. Before the damage, Bacchus had a smaller fountain bowl in his hand. Some fragments of the catchment basin in the lower part of the fountain have been preserved but now it is covered with soil. 
After the reconstruction, the Bacchus sculpture with the street lamp will be reconstructed, the soil around the fountain will be removed, and the catchment basin will be restored. The height of the fountain will amount to $8.6 \mathrm{~m}$.

When examining the mascarons, we found small and large orifices for water discharge (Figure 1B). These orifices were made in all four mascarons located around the perimeter of the large bowl. The large orifices are located in the mouths of the mascarons and the small ones - in the curls. Each mascaron has six small orifices.

Our task was to restore the technology of the fountain's operation. Unfortunately, we found no information about its operation, location of the pipelines, or position of the jets in historical documents (including old photos). Therefore, it was necessary to analyze the technology of operation of similar fountains.

\section{Methods}

The problem of fountain restoration can be solved in several stages. In the course of our

A)

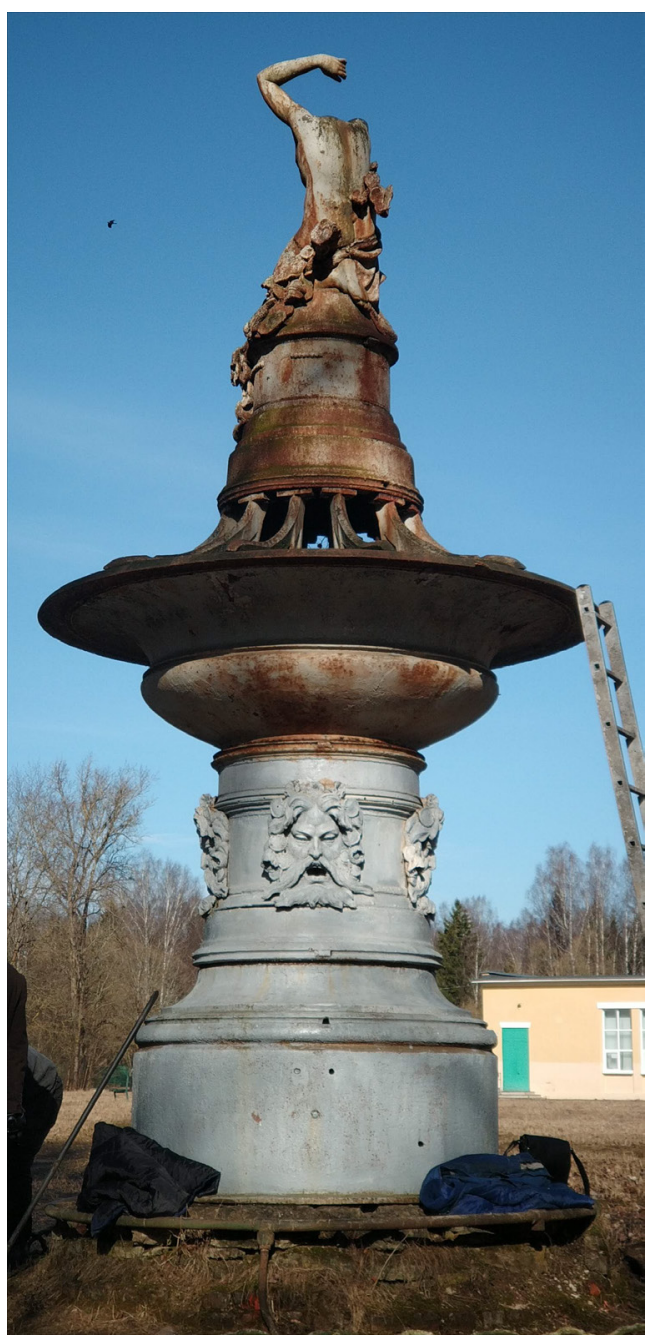

research, we adopted the experience of studying and reconstructing the Fountain of Neptune in Bologna (Apollonio et al., 2017).

At the first stage, we aimed to determine the location of the catchment basin in relation to the orifices in the mascarons. For this purpose, pits were made along the perimeter of the base of the bowl with a depth of up to $0.9 \mathrm{~m}$ to discover the structural elements of the catchment basin (Figure 2A). We measured the dimensions of the fountain (including the catchment basin) and determined the diameters of the orifices using a measuring tape (Figure 2B). We also made photos to examine the internal structure of the fountain. Toward that end, a photo camera was placed in the large orifices in the mascarons, and one of the team members was lifted to the large bowl.

The architectural and engineering parts of a fountain are inextricably linked and complement each other (Shakerin, 2004). The water jets unfold the architectural appearance of the structure and enhance its perception, and the architectural
B)

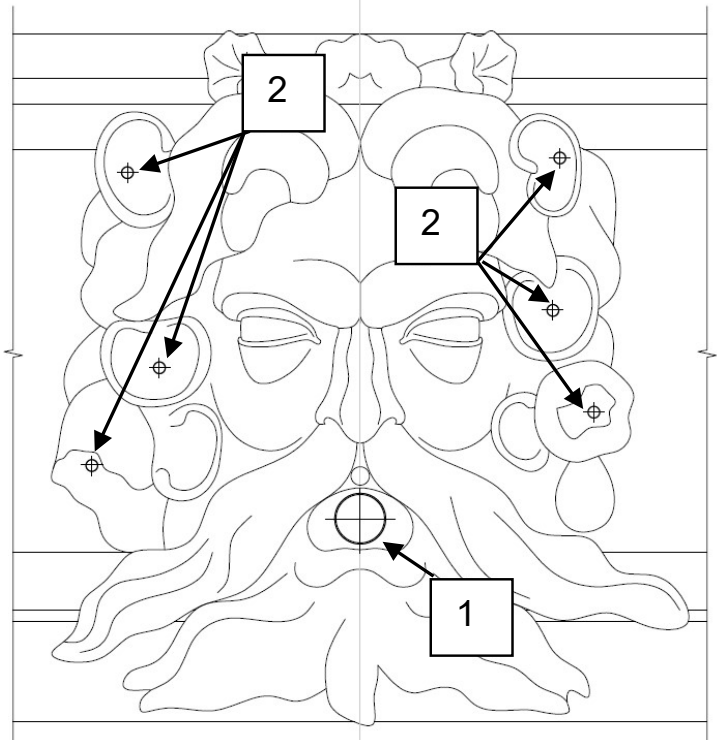

Figure 1. A) cast-iron fountain; B) mascaron: 1 - large orifices, 2 - small orifices 
A)

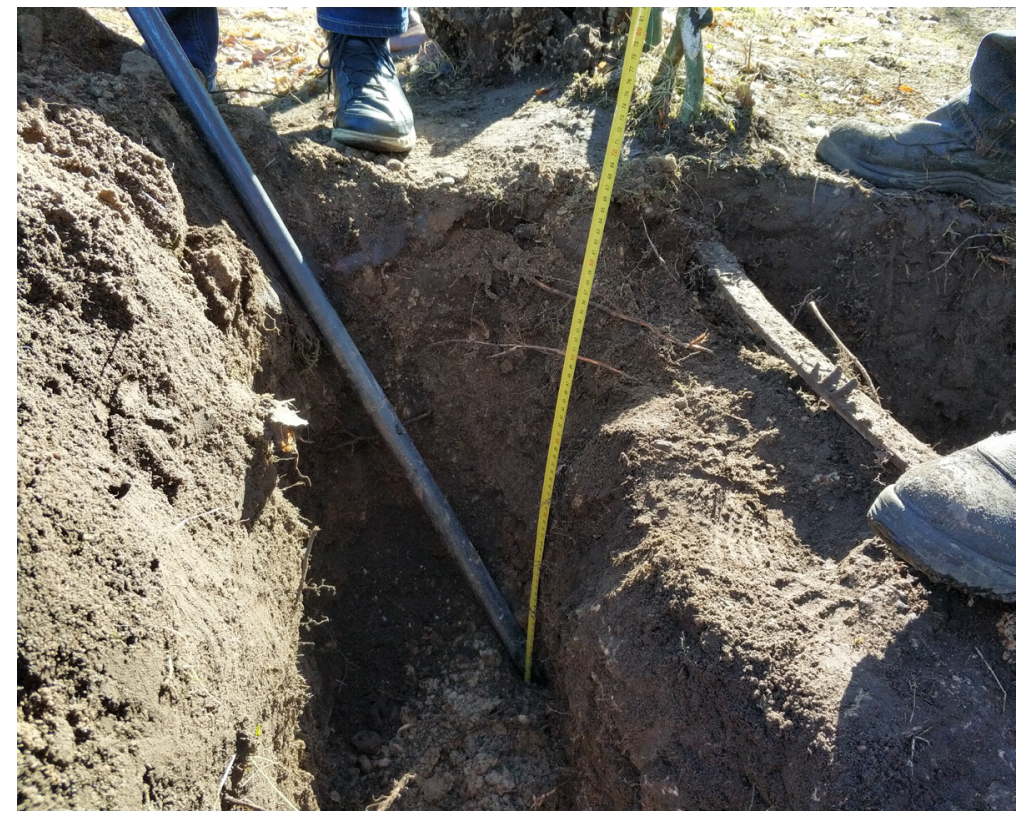

B)

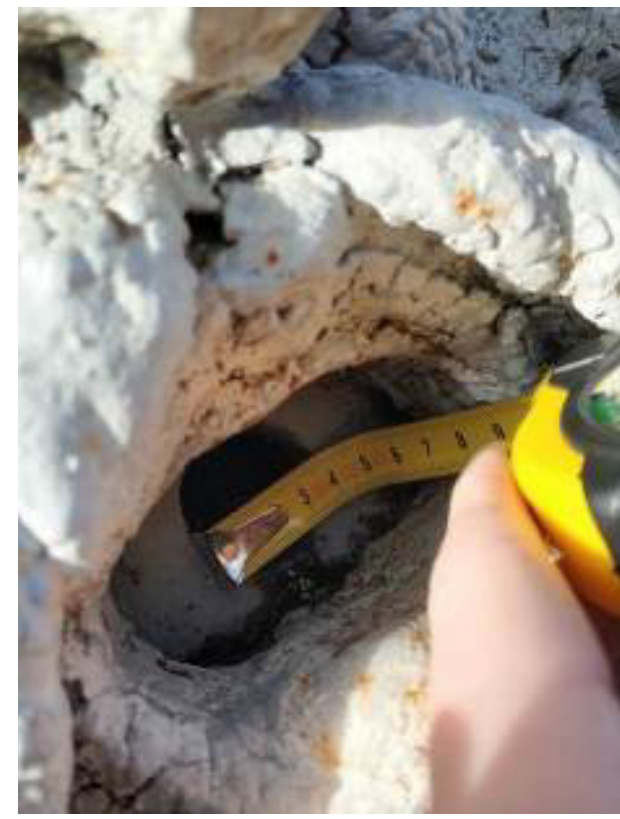

Figure 2. Fountain examination

elements hide the engineering mechanisms of the fountain. To reconstruct the equipment of the fountain under consideration, we analyzed similar fountains in St. Petersburg: the Roman Fountains in Peterhof, the fountain on the Universitetskaya Embankment, and the fountain in front of the building of the Military Medical Academy. These fountains have several bowls located throughout the height; water flows out through the orifices and spills over the edges of the bowl. Based on the results of the analysis, several options for the fountain's operation were proposed (Figure 3). According to option A, a water jet, formed above the hand of Bacchus, filled the small bowl with water. Spilling over the edges of the small bowl, water was directed into the large bowl where it accumulated at the base and then flowed out through the large and small orifices in the mascarons into the catchment basin. According to option B, the upper bowl was filled with water in the same manner as described above. Spilling over the edges of the small bowl, water was directed to the base of the large bowl where it accumulated at the bottom and then was discharged into the catchment basin through a special connection element. Water was supplied to the mascarons through a separate pipeline. According to option $\mathrm{C}$, water was supplied to the upper bowl and the mascarons through separate pipelines. However, in contrast to option B, due to the arrangement of deflectors on the structural ribs of the large bowl, water from the small bowl fell directly to the catchment basin and not to the large bowl. According to option D, no water was supplied to the small bowl. Instead of a water jet in the hand of Bacchus, it was proposed to install a street lamp and supply water through separate pipelines only to the orifices in the mascarons.

We also analyzed the territory of the park to discover the location of the pipelines supplying water to the fountain. When examining the plot plan and the pits next to the fountain, we found a cast-iron pipeline with threaded fittings, which came out of the ground near the base of the bowl and was connected to a radical collecting main made of cast-iron pipes. The collecting main had round orifices around the perimeter of the bowl. During the analysis of historical documents, it was determined that the pipeline was intended for the irrigation of green areas, which were located at the catchment basin and the large bowl at certain stages of the fountain's existence. No original water supply pipelines survived. Therefore, we designed the system from scratch.

To calculate the distance of jet travel, Bernoulli's equation was used. To calculate the resistance of the supply pipelines, the Weisbach and Darcy-Weisbach equations were used.

We also needed to determine the points of connecting and emptying the fountain to complete the project. As a connection point, we chose the water supply system of a public toilet, which is located on the square near the fountain. Since the fountain is located in a pedestrian area, which cannot be approached by vehicles for emptying the fountain, it is necessary to develop a system that will allow for water diversion and disposal since it is impossible to discharge water from the fountain into the nearby water body.

\section{Results and Discussion}

As a result of the survey, we discovered a service opening in the foundation under the base of the large bowl (Figure 4A), which had previously been used 
to connect the pipelines. When examining the inner cavity of the fountain, we found that the large bowl and the base under it do not have internal partitions between them. A vertical cast-iron pipeline is located along the axis of the fountain, which is presumably left from the plant irrigation system (Figure 4B).

Taking into account the historical experience of using the fountain as a street lamp and following the examination of the inner part of the structure, we decided to restore the fountain according to option $D$ (Figure 3). The combination of water movement and lighting is widely used in modern fountains (Visconty et al., 2016).

As a result of the survey, we clarified the dimensions of the catchment basin and, based on that, calculated the trajectories of the jets and water heads upstream of the large and small orifices (located the highest in the mascaron curls). Remnants of brickwork of an old catchment basin were found in the pits. Thus, the catchment basin has the shape of a ring and is bounded on the outside by a rim, and on the inside - by a stone foundation of

A)

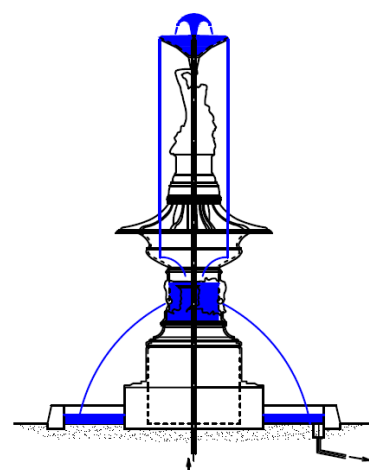

A)

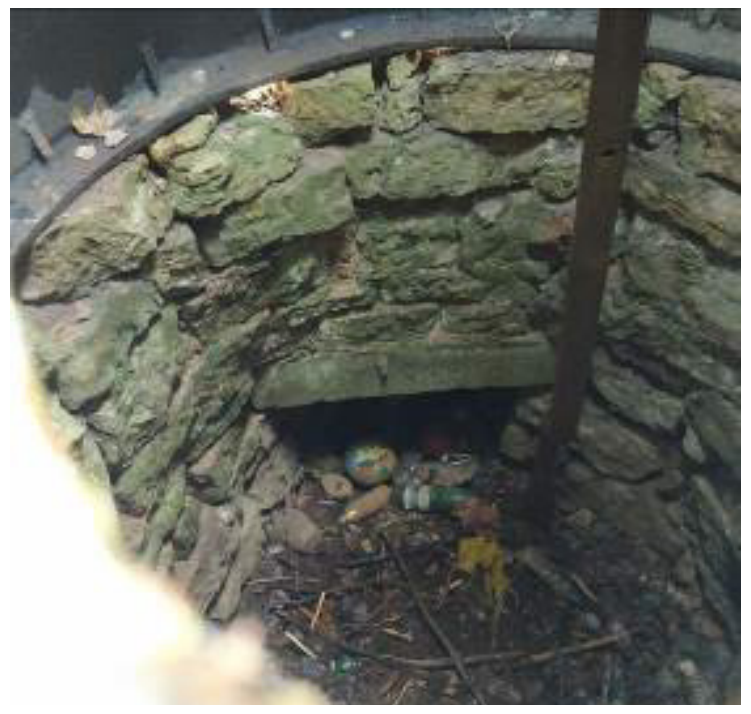

the base of the bowl. The diameter of the catchment basin on the outer rim is $4.9 \mathrm{~m}$, and the width of the radial chute is $0.6 \mathrm{~m}$. For the purposes of engineering analysis, we assumed that the jets should fall into the center of the radial chute of the catchment basin. The distance from the center of the chute to the large orifices is $1.7 \mathrm{~m}$, and to the small orifices $-1.57 \mathrm{~m}$. The height of the large orifices located above the chute of the catchment basin is $2.17 \mathrm{~m}$, and that of the small orifices $-2.48 \mathrm{~m}$. Based on the known equation of the jet trajectory (Bistafa, 2015; Gordon, 2013; Peszynski et al., 2019), the required water heads upstream of the orifices were determined. For the large orifices, the water head is $0.354 \mathrm{~m}$, and for the small orifices $-0.264 \mathrm{~m}$. Using Bernoulli's equation, we calculated the water flow rates for each type of orifices. For the large orifices, the flow rate is $1.85 \mathrm{l} / \mathrm{s}$, and for the small orifices - $0.04 \mathrm{l} / \mathrm{s}$.

Since the orifices are located at different heights, we decided to provide separate piping systems for the large and small orifices in order to ensure the required jet trajectories and convenient control

C)

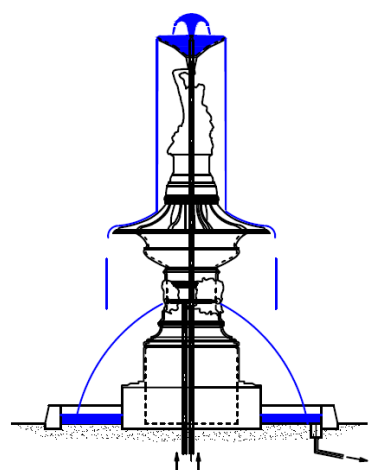

D)

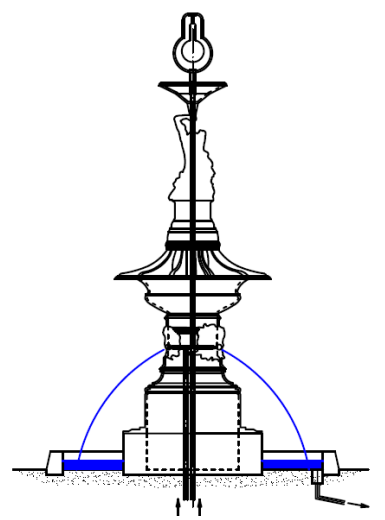

Figure 3. Options of the fountain's operation

B)

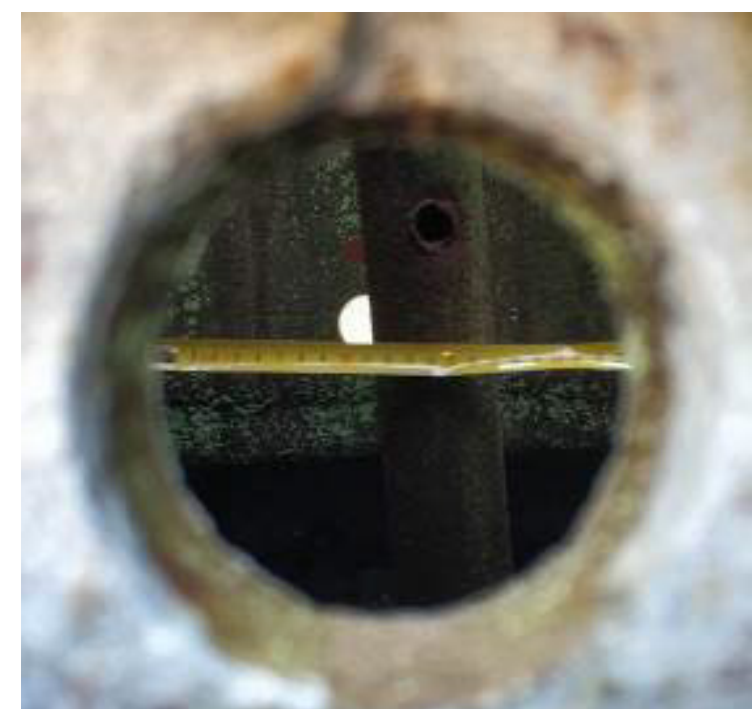

Figure 4. Examination of the inner cavity of the fountain: A) service opening, B) vertical pipeline 
of the jet travel distance. We also determined the costs for each system by multiplying the number of the corresponding orifices by the water flow rate. For the system of the large orifices, the flow rate is $7.4 \mathrm{l} / \mathrm{s}$, and for the system of the small orifices $0.96 \mathrm{l} / \mathrm{s}$. Based on the costs obtained, we performed a hydraulic analysis of the pipeline systems. The pipes inside the fountain were assumed to be made of stainless steel; the diameters of the main supply pipelines are $60 \mathrm{~mm}$ for the large orifices and $25 \mathrm{~mm}$ for the small orifices. The body of the fountain had four branch pipes on the inside (32 $\mathrm{mm}$ for the large orifices, $10 \mathrm{~mm}$ for the small orifices). Under the mascarons, the pipelines with a diameter of $10 \mathrm{~mm}$ branched out in six directions, and with the help of reducers, they were narrowed for $6 \mathrm{~mm}$ orifices in the curls.

The pipelines laid outside from the pumping station to the fountain were made of low-pressure polyethylene.

In the course of the hydraulic analysis for the system of the large orifices, head losses amounted to $3.29 \mathrm{~m}$, and for the system of the small orifices to $8.60 \mathrm{~m}$.

For each system, a downhole pump was selected, which is quite common in engineering practice (Sanchez, 2004). Both pumps were placed horizontally in the plastic housing of the pumping station, in cooling jackets equipped with meshes for mechanical cleaning. The pumping station is located next to the fountain (Figure 5).

The next important step was to develop systems for supplying water to the fountain and emptying it. It is planned to lay a pipeline (6) with a pipe diameter of $20 \mathrm{~mm}$ from the water supply system of the public toilet (1) to the catchment basin of the fountain (2) (Figure 5). To ensure wastewater disposal, we decided to lay a gravity pipeline (7) with a pipe diameter of $200 \mathrm{~mm}$ from the drainage well (3) to the collecting well (5) wherefrom water can be pumped out by sewage trucks when shutting down the fountain for winter.

Figure 6 shows a complex of engineering solutions that ensure the fountain's filling with water, operation, and shut-down for winter. The fountain is filled with water in the following way. The ball valve (14) as well as the valves (16), (17), (18), and (19) open. Through the pipeline (6), water is supplied to the catchment basin of the fountain from the toilet. From the catchment basin, water flows by gravity to the pumping station (4) through the pipeline (11). Having reached the design trigger level, the pumps turn on automatically, supplying water to the mascarons: through the pipeline (9) — to the large orifices, and through the pipeline (10) — to the small orifices. Through the orifices, water enters the catchment basin and returns to the pumping station through the pipeline (11). By adjusting the valves (18) and (19), the trajectories of the water jets are controlled. The design level of water in the catchment basin ( $90 \mathrm{~mm}$ from the bottom) is maintained by adjusting the valve (20) on the pipeline (13). The design level of water cannot be exceeded. For that purpose, an overflow pipe (12) is provided, which diverts excess water to the drainage well (3) and further to the sewerage system (7). When the design level of water in the catchment basin is reached, the automation system closes the solenoid valve (15), and the water supply through the pipeline (6) is stopped.

During the fountain's operation, water losses due to evaporation and droplet carry-over are possible. Therefore, the make-up of the circulating water system is ensured with the help of the automation system. When the level of water in the catchment basin drops to $80 \mathrm{~mm}$ from the bottom, then, following the signal from the water level sensor in the toilet, the solenoid valve (15) opens, and makeup water enters the catchment basin through the pipeline (6) until the level of water reaches $90 \mathrm{~mm}$ from the bottom. Then the solenoid valve (15) closes automatically. At nighttime, the fountain turns off due to the shutdown of the pumping units, and all the water flows to the pumping station (4). In the morning, the fountain turns on due to the forced switching-on of the pumping units. At the moment of the shutdown of the pumping units, the ball valve (14) must be closed.

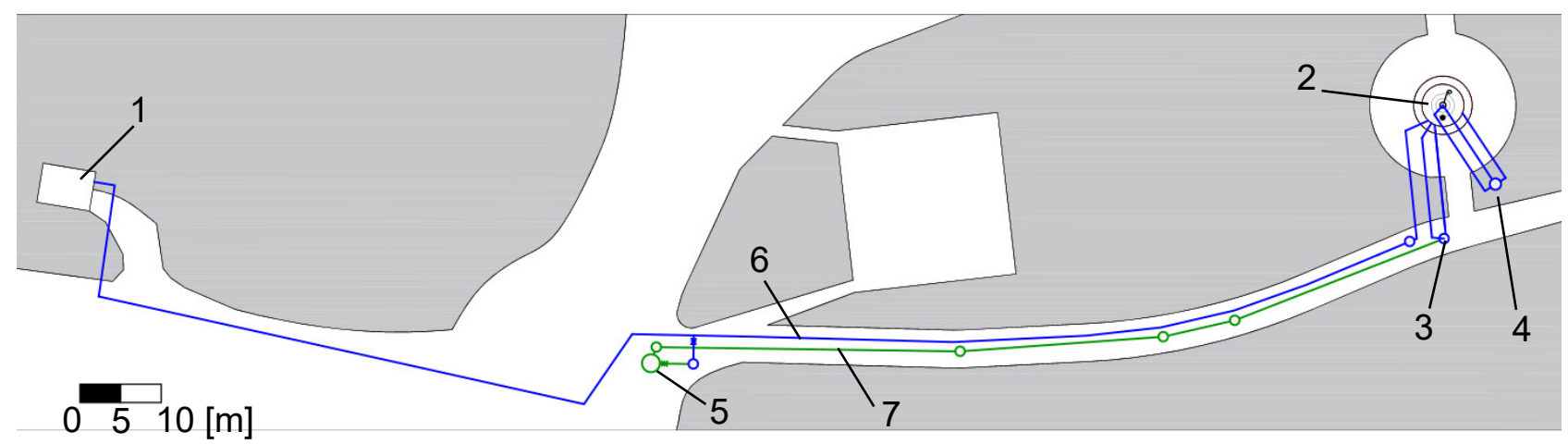

Figure 5. Layout plan of the water supply and sewerage systems of the cast-iron fountain: 1 - public toilet, 2 - cast-iron fountain, 3 - drainage well, 4 - pumping station, 5 - well to pump out wastewater by sewage trucks, 6 - water pipeline, 7 - sewerage system 


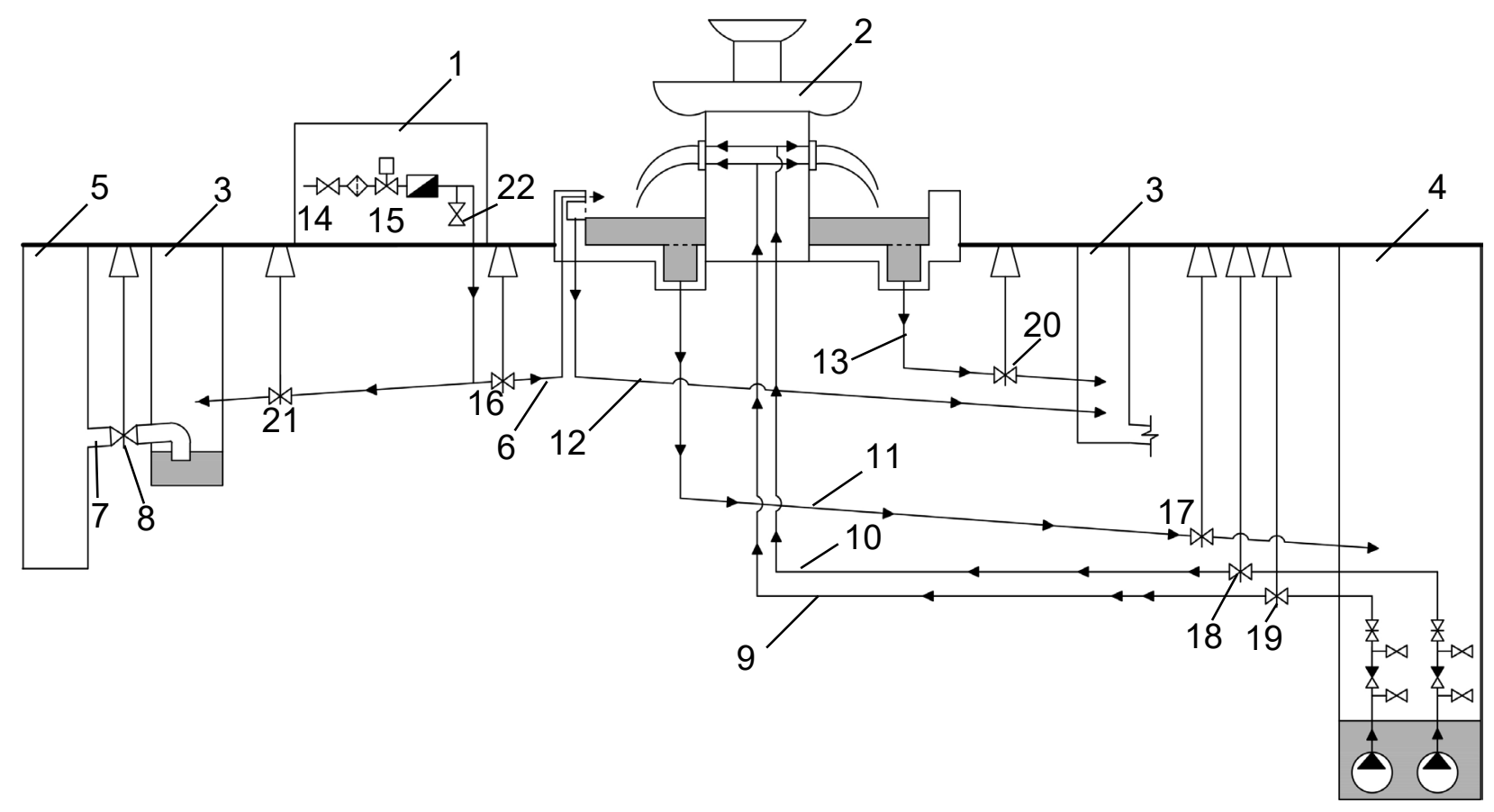

Figure 6. Schematic of the fountain's operation

The fountain is emptied by closing the ball valve (14), closing the valve (17), and orifices the valve (20). In this case, the pumps continue to operate, pumping water into the drainage well (3) through the pipeline (13). The pumps turn off when the level of water at the pumping station (4) reaches the target shutdown level. After that, it is necessary to empty the filling/ make-up system (6), the pipelines supplying water to the mascarons (9) and (10), and the pipeline (11). To do this, it is required to open the drain valve (22) in the toilet, the valve (8) at the drainage well, and the valve (17). Then, it is required to open the drain valve at the pumping station. As a result, water from the pipeline (6) enters the sewerage system (7). Water from the pipelines (9), (10), and (11) drains to the pumping station (4). It must be pumped out to the drainage well (3) using a portable pump. Water from the sewerage system (7) enters the well (5) where it accumulates in the settling section. After emptying, all the water is pumped out of the well (5) by a sewage truck.

Since the fountain is located in a park ensemble, no wastewater treatment system was arranged. To prevent pipeline clogging, grates were provided in the pits. In case of water quality deterioration (increase in color or odors), it is recommended to either replace the water in the fountain or use disinfectant tablets.

\section{Conclusions}

In the course of the study, we examined an old fountain and designed systems ensuring its filling with water, operation, and shut-down for winter. We also developed an approach to the reconstruction of old fountains, which includes the analysis of historical documents, the assessment of the operation of similar fountains, and the use of modern energy-efficient process flow schemes. The restoration of this fountain will enrich the landscape architecture of Pavlovsky Park and create favorable conditions for visitors during the hot season. The experience described in the paper is a clear example of work required for the reconstruction of the engineering systems of the lost fountains. 


\section{References}

Alcocer, V. G., Ballesta, J. J. and Hernanz, E. S. (2017). Conservation and restoration works of the Four Sewers Fountain in Daganzo (Madrid, Spain). Ge-Conservación, Vol. 11, pp. 172-179. DOI: 10.37558/gec.v11i0.470.

Apollonio, F. I., Ballabeni, M., Bertacchi, S., Fallavollita, F., Foschi, R.and Gaiani, M. (2017). From documentation images to restauration support tools: a path following the Neptune fountain in Bologna design process. The International Archives of the Photogrammetry, Remote Sensing and Spatial Information Sciences, 2017 GEOMATICS \& RESTORATION - Conservation of Cultural Heritage in the Digital Era, May 22-24, 2017, Florence, Italy, Vol. XLII-5/ W1, pp. 329-336. DOI: 10.5194/isprs-archives--XLI-5-W1-329-2017.

Bistafa, S. R. (2015). Euler's friction of fluids theory and the estimation of fountain jet heights. The European Physical Journal H, Vol. 40, Issue 3, pp. 375-384. DOI: 10.1140/epjh/e2015-60031-2.

Bonnie, R. and Richard, J. (2012). Building D1 at Magdala revisited in the light of public fountain architecture in the late-HelIenistic East. Israel Exploration Journal, Vol. 62, Issue 1, pp. 71-88 (1). DOI: 10.5281/zenodo.262938.

Chang, Y.-H., Wu, B.-Y. and Lai, C.-F. (2015). A study of the ecological benefits of the green energy landscape fountain. Ecological Engineering, Vol. 75, February 2015, pp. 128-136. DOI: 10.1016/j.ecoleng.2014.11.021.

Doubal, J. (2017). The restoration of the Stone Fountain in Kutná Hora: An assessment of the contemporary intervention within the context of repairs throughout history. Studies in Conservation, Vol. 62, Issue 7, pp. 371-383. DOI: 10.1080/00393630.2016.1206246.

Gordon, M. (2013). The mathematics of fountain design: a multiple-centres activity. Teaching Mathematics and its Applications: An International Journal of the IMA, Vol. 32, Issue 1, pp. 19-27. DOI: 10.1093/teamat/hrs013.

Hynynen, A. J., Juuti, P. S. and Katko T. S. (eds.) (2012). Water fountains in the worldscape. Kangasala: International Water History Association and KehräMedia Inc., 222 p.

Juuti, P. S., Antoniou, G. P., Dragoni, W., El-Gohary, F., De Feo, G., Katko, T. S., Rajala, R. P., Zheng, X. Y., Drusiani, R. and Angelakis, A.N. (2015). Short global history of fountains. Water, Vol. 7, Issue 5, pp. 2314-2348. DOI: 10.3390/ w7052314.

Peszynski, K., Perczynski, D. and Piwecka, L. (2019). Mathematical model of a fountain with a water picture in the shape of an hourglass. EPJ Web of Conferences, Vol. 213, 02064. DOI: 10.1051/epjconf/201921302064.

Sanchez, J. (2004). Renovation project returns Chicago fountain to its youth. World Pumps, Vol. 2004, Issue 450, pp. 37-39. DOI: 10.1016/S0262-1762(04)00144-0.

Shakerin, S. (2004). Microcontrolled water fountain: a multidisciplinary project. International Journal of Engineering Education, Vol. 20, No. 4, pp. 654-659.

Visconty, P., Constantini, P. and Cavalera, G. (2016). Smart electronic system for dancing fountains control capable to create water and lighting scenarios synchronized with a music track. ARPN Journal of Engineering and Applied Sciences, Vol. 11, No. 9, pp. 5669-5675.

Xue, F., Li, X., Ma, J. and Zhang, Z. (2015). Modeling the influence of fountain on urban microclimate. Building Simulation, Vol. 8, Issue 3, pp. 285-295. DOI: 10.1007/s12273-014-0210-7.

Yenigün, K., Kürkçüoğlu, C., Karakaş, M., Gerger, R., Aydoğdu, M. H. and Gümüs, V. (2017). Historical water structures of Şanliurfa; fountains. In: Baba, A., Gündüz, O. and Tayfur, G. (eds.) IWA-PPFW 2017. IWA $2^{\text {nd }}$ Regional Symposium on Water, Wastewater and Environment. The Past, Present and Future of the World's Water Resources, March 22-24, 2017, Çesme - Izmir, Turkey, pp. 430-439. 


\title{
РЕКОНСТРУКЦИЯ СИСТЕМ ВОДОСНАБЖЕНИЯ И ВОДООТВЕДЕНИЯ ЧУГУННОГО ФОНТАНА В ПАВЛОВСКЕ
}

\author{
Святослав Викторович Федоров, Юрий Вячеславович Столбихин*, Виктор Михайлович Васильев \\ Санкт-Петербургский государственный архитектурно-строительный университет \\ 2-ая Красноармейская ул., 4, Санкт-Петербург, Россия \\ *E-mail: stolbikhin@bk.ru
}

\begin{abstract}
Аннотация
Восстановление старых фонтанов имеет важное значение для культурной жизни общества, поскольку позволяет донести до нашего времени историческое наследие и сохранить архитектурный дух прошлого. Также фонтаны создают благоприятную атмосферу в летний период времени, увлажняя воздух. В данном исследовании разработан подход к восстановлению инженерных систем и технологии функционирования старинного фонтана в г. Санкт-Петербурге. Методы: Подход включал в себя подробное обследование корпуса чугунного фонтана и выполнение шурфов рядом с фонтаном для обнаружения сборного бассейна и установления его габаритных размеров, оценку работы фонтанов-аналогов, анализ исторической документации (старинных фротографий) и выполнение проектных работ по созданию инженерных систем. Результаты и обсуждение: Получены размеры фонтана и сборного бассейна, диаметры технологических отверстий. Определены траектории струй фонтана и схема его функционирования. Выполнены гидравлические расчеты систем, подобрано необходимое оборудование. Представлена технологическая схема работы фонтана в режимах заливки, функционирования и консервации на зиму.
\end{abstract}

\section{Ключевые слова}

Фонтан, реконструкция, водоснабжение, водоотведение, обследование, гидравлический расчет. 